\title{
Oceanography
}

CITATION

Kappel, E.S. 2017. Our awesome, inspiring US Park Rangers and the value of public service. Oceanography 30(2):5, https://doi.org/10.5670/oceanog.2017.201.

$\mathrm{DOI}$

https://doi.org/10.5670/oceanog.2017.201

COPYRIGHT

This article has been published in Oceanography, Volume 30, Number 2, a quarterly journal of The Oceanography Society. Copyright 2017 by The Oceanography Society. All rights reserved.

USAGE

Permission is granted to copy this article for use in teaching and research. Republication, systematic reproduction, or collective redistribution of any portion of this article by photocopy machine, reposting, or other means is permitted only with the approval of The Oceanography Society. Send all correspondence to: info@tos.org or The Oceanography Society, PO Box 1931, Rockville, MD 20849-1931, USA. 


\section{Our Awesome, Inspiring US Park Rangers and the Value of Public Service}

I first visited the national parks in the southwestern United States in the late 1970 s as a Cornell University undergraduate enrolled in the geology department's six-week Western Field Course. Over the decades, I've been back many times, as a scientist and as a parent. In May, I revisited many of these parks with my now youngadult daughter, including the Grand Canyon, Petrified Forest, and Saguaro in Arizona, Arches and Canyonlands in Utah, and Mesa Verde in Colorado. As always, I was awed-awed not only by the natural beauty of these places and the geologic forces that carved them but also by the US park rangers. These federal government employees were knowledgeable, personable, enthusiastic, and eager to share information about the geological or cultural history of the park or their favorite hikes. They patiently answered visitors' questions, pointed lost wanderers in the right direction, and asked where the visitors hailed from. It was clear that the park rangers took pride in their work and in the national parks and monuments they served and called home.

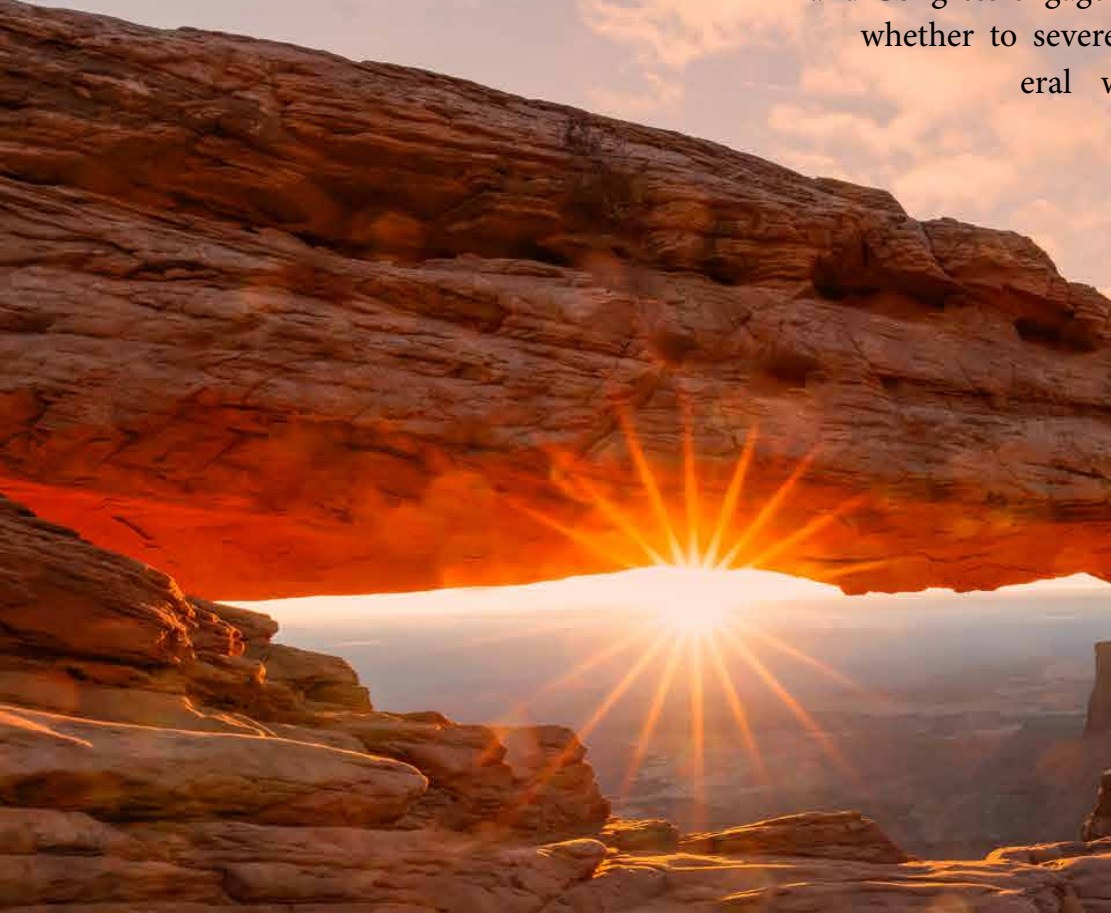

Their professionalism and dedication was inspiring, and reflected a deep commitment to public service in an era where such service is not universally honored.

Unseen to the public eye are thousands of other equally dedicated public servants, many of whom are scientists working in government laboratories, offices, and in the field. Not that many decades ago, views of the Grand Canyon and other magnificent sites were marred by smog. Today, the views are usually clear, thanks to our colleagues whose research helps to ensure that the air is clean. Other government scientists test for contaminants in our rivers and aquifers to ensure that the water from taps and fountains is potable. They monitor earthquake and volcanic activity, and forecast weather so that we have time to get to safety should there be some imminent threat. And so on. Agency scientists contribute to the well-being of our nation in so many ways that go unnoticed-and are taken for granted-by people who don't know or appreciate what government scientists do for them.

It's budget season in Washington, DC, with the new US Administration and Congress engaged in a dialog about whether to severely shrink the fedal workforce, including thousands of workers in agencies that employ scientists. No one can accurately predict how many jobs might be lost, or which scientific research might be affected. But uncertainty has its own consequences. One concern is maintaining morale among the current staff whose work is denigrated or severely curtailed for lack of sufficient budgets or staff. Another concern is failing to recruit future generations of top students who otherwise would consider federal service their calling.

It's probably impractical to propose that the Cabinet secretaries and Congressional committee chairpersons who will ultimately decide the fate of federal science take a field trip to the West. But if my recent experience is any guide, a lot of eyes would be opened by listening to a park ranger tell the story of the cliff dwellings in Mesa Verde: how Native Americans built them, gathered and stored food and water in a relatively dry climate, worshiped, and then abandoned the mesa after living there for approximately 600 years.

Here's hoping that visitors will continue to be able to enjoy the beauty of the US national parks and learn about their geological and cultural history for decades to come, and that government-sponsored science will be valued for its immense service to our country and its people.

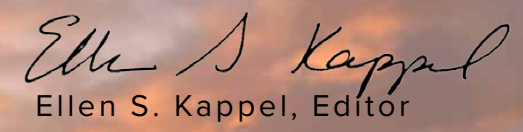

